\title{
Customer Satisfaction Post Car-Sales in Service Centers Using Experiential Marketing
}

\author{
A. Govindarajan ${ }^{1}$, S. Jyothirmaye Reddy ${ }^{2}$, Kiran Kumar Chandriah ${ }^{3}$, \\ T. Ch. Anil Kumar ${ }^{4}$, D. Balamurugan ${ }^{5}$ and G. Kannan ${ }^{6}$ \\ ${ }^{1}$ Department of BBA. KL Business School, Koneru Lakshmaiah Educational Foundation, \\ KL University, Green Fields, Vaddeswaram, Guntur, Andhra Pradesh, India. \\ ${ }^{2}$ Department of Management Studies, Jagan's Institute of Engineering \& \\ Technology, Choutapalem, Nellore District, Andhra Pradesh, India. \\ ${ }^{3}$ Project Manager, Mercedes Benz Research and Development India Pvt. Ltd., Bangalore, Karnataka, India. \\ ${ }^{4}$ Department of Mechanical Engineering, Vignan's Foundation \\ for Science Technology and Research, Vadlamudi, Guntur, Andhra Pradesh, India. \\ ${ }^{5}$ Department of Computer Science and Engineering, Sona \\ College of Technology, Salem, Tamil Nadu, India. \\ ${ }^{6}$ College of Management, SRM Institute of Science and Technology, \\ Ramapuram, Chennai, Tamil Nadu, India.
}

\section{ABSTRACT}

Customer satisfaction is seen as an index to find the emotional state of a customer that defines the positive aspirations to define the joy of a customer. The marketers focus mainly on making their customers happy, however, the marketing or servicing tactics or campaigns cannot do this but a positive experience of a user with emotional bonding can do this. Hence, with such motivation, the present study finds how well the customers are happy post sales of a car or servicing of a car. This study finds the customer experiences on how their vehicles are serviced and this defines the measure of satisfaction and customer loyalty. The study conducts a questionnaire survey on 1000 patients at different service center executives and car owners. The analysis is conducted using SPSS tool to find the positive experience and its significant impact on satisfaction and customer loyalty.

\section{KEY WORDS: CUSTOMER SATISFACTION, CAR SERVICE, EXPERIENTIAL MARKETING, LOYALTY.}

\section{INTRODUCTION}

Today, sales are growing in India's automotive industry as demand for all types of cars is gradually rising, and the motor vehicle sector has evolved over the past months (Rather et al, 2020). It has been for some reasons in this industry to increase the living standards of middle

Biosc Biotech Res Comm P-ISSN: 0974-6455 E-ISSN: 2321-4007

\section{crossef}

Identifiers and Pagination

Year: 2021 Vol: 14 No (6) Special Issue

Pages: $328-334$

This is an open access article under Creative

Commons License Attribn 4.0 Intl (CC-BY).

DOI: $h$ ttp://dx.doi.org/10.21786/bbrc/14.6.68 class families and raise disposable income, especially for middle-class Indian families (Le et al., 2019). There are several reasons for this increase. Another factor behind this increase is that the Indian government has taken several measures, such as enabling 75\% Foreign Direct Investment and deregulation of foreign currency, lowered import tax rates, and financial reforms that helped to purchase more good cars while financing them(Ferreira et al., 2020, Yeh et al., 2019).

India is a market with rapid development, allowing foreign companies to invest increasingly in policy initiatives in India (Ihtiyar et al ., 2019).Tax facilities are available by means of policy actions to establish overseas companies in China in order to reduce their product costs and provide consumers with additional cost-benefits

Article Information
Received: $27^{\text {th }}$ March 2021
ter revision: $05^{\text {th }}$ June 2021
$\mathrm{brc} / 14.6 .68$


(Batat et al., 2019). And as there is a boom in the Indian car industry, particularly in vehicles, as a result of the growth in customer purchasing skills, there is also a huge demand for high-end cars under supervision (Garcia et al., 2018).

Consumption attitudes of consumers inevitably mean a distinction in the use of services/goods and builds positive/negative impressions (Wiedmann et al., 2018). Businesses are constantly and intentionally creating different moments for their clients to truthfulness or to distinguish themselves with product, service and atmosphere and to generate different positive or negative impressions (Skandalis et al., 2019) . Researchers both in academia and in practice are interested in understanding and analyzing consumer interactions (Smilansky et al., 2019). The differentiation of tactics and their place in the business market requires insights into generating unforgettable experience in services and products and delivering attractive interactions for consumers. The recent development in the computing devices such mobile devices( Saravanan et al., 2016, Saravanan et al., 2012), wireless networks (Saravanan et al.,2016) , computers etc., helps the marketing field by promoting customers online. This work contributed to a modern marketing perspective, known as experiential marketing (Rather et al., 2019).

Many companies, such as Mini and Tesla in the automobile industry in mass apparel among many others, reflect the experiential approach to online marketing (Lin et al., 2019). An important concept in experimental marketing is that meaning is not only derived from the purchase and use of resources and products, but from its hedonic component and the consumption experience itself (Pratminingsih et al., 2018). Marketing theorists have often differentiated between hedonic and functional ideals. It was also recognized that workers ought to consider the views of counterparts and the capacity to function behind those perceptions (Wahyuningtyas et al., 2017). Hospitality and tourism are among the fastest growing industries in the global economy, owing to their reliance on services/goods consumer experience (Araci et al., 2017 ). While there is a practical background in this industry, the use of experiential marketing and social assessment modules has yet to be successfully synchronized (Shieh et al., 2017).

This paper is thus primarily intended to test experiential values by evaluating experiential modules. In order to achieve purchasing satisfaction, the second goal is to explore the importance of experiential values. If the framework of marketing has changed to produce compelling retail interactions for customers, the examination of these questions further reinforces awareness of the problem as well as postulates creative perspectives into how certain variables interact. Furthermore, proof of those problems is our immediate answer, because of its heterogeneity and scope, to the many recent calls to further study the definition.

Background: Experiential marketing is a customer engagement term. Sellers struggle to touch on the sense, feeling, acting, and thinking and develop a meaningful and satisfying shopping experience (Mukiira et al., 2017). Experiential marketing often gives meaning to the entire product or service by affecting the experience of a customer by using a product or services of a business (Levy et al., 2020). A seller needs not only to concentrate on particular experiences, but instead to think strategically about what kind of experiences they have to offer and who they are attracted to (Datta et al., 2017). Experiential marketing is a way to create customer experience through the use of 5 senses for goods or services, affective experience, creative thoughts (think), customer experience with the body through physical behavior and lifestyles and experiences as a result of interactions and the development of social experience (Budovich et al., 2019).

Based on the views of these researchers, the writers argue that experiential marketing involves the development of stimuli for consumers who use goods using five different senses, affective perceptions, imaginative thought experience and the body's awareness of physical behavior and life style (Ali shah et al., 2018). There are many approaches to evaluating customer service (Eroglu et al., 2019).The standards for customer service in the automobile industry are as follows:

- The conformity or mismatch of customer preferences and current production of the goods or services of the business is expected to be fulfilled (Muthiah et al., 2017). In this situation, a stronger focus would be placed on quality of service, which has component standards for customer service (including cleaning of site, pace of service and employee friendliness/ courtesy) (Suhaily et al., 2018).

- The goal of repurchase is to assess customer loyalty by asking if the customer shops or re-uses the service of the firm (Lee et al., 2017). Quality service can generate customer loyalty, where the quality of service is considered as positive by customers. For example, a certain hospital is the reference in the mind of customers for the first time if one faces health issues later (Widowati et al., 2017).

- The willingness to prescribe is that someone would not hesitate to propose a commodity to friends or family, which is an integral indicator of analysis (Suluk et al., 2019). When the received service is perceived to be as intended, the quality of the service should be viewed as reasonable and satisfactory so that customers can either buy or choose to use services and, as a result, recommend it to others (Gheorghe et al., 2017).

- Sales Satisfaction Index: The objective of the report is to assess client satisfaction across six device elements, including ordering, distribution, sales representative, trainers, paperwork and contracts (Boonmalert et al., 2020).

- Customer Satisfaction Index: The report showed how happy car buyers are with various car providers (Tangkuman et al., 2020). Eight measurements of a vehicle are measured, including recorded issues, 
service level, user-friendly service, consultant, start of the service, service delivery, and implementation experience (Yazici et al., 2017) .

- Initial Quality Study: The description designs new vehicles with a quality standard for nine components of the structure, including the outside components, internal components, travel dynamics, controls for features and show, audio, seating, motor and transmission (Hong et al., 2020). These modules are divided into two different categories; design quality and functional features (Gallo et al., 2019).

Proposed Method: Descriptive architecture was used in this analysis. Descriptive studies are those studies which describe a specific person or group's characteristics. This means that the investigator needs to be able to accurately determine whether he wishes to assess and identify suitable measurement tools. The research obtained both primary and secondary data. The main data collection method was by means of questionnaires. The secondary statistics are those previously compiled by someone else and already statistically transmitted. The data is analyzed by means of mean, correlation and recovery. For the meaningful outcomes, the data obtained in the previously described form is tabled in simplified form. Two types of scales were used in this research: Nominal and Likert. A nominal scale showing demographic factors was used in this analysis. Likert scale was used in the analysis for certain questions, e.g. to determine the impact of experience marketing on consumers' behaviour.

Strategic Framework: Sense marketing offers 5 senses in order for vision, hearing, touch, taste and scent to be tangible. Sense marketing may be used to differentiate companies and products, to encourage customers and to maximize goods' worth. Feel marketing demands the inner feelings and feelings of customers with the intention of meeting up with feelings which range from a very optimistic feeling of satisfaction and confidence related to a brand. Conceive campaign offers for the mind with the intention of meeting customers in a psychologically vital way. Consider demands by surprise, suspense and incitement to reflect on market convergence and differing rationales. Campaigns are fundamental to modern pieces of creativity. Act marketing improves the lives of customers by relying on their physical meetings, optional means to do activities, elective lifestyles and relationships.

Balanced approaches to behavioral modification are just one of the alternatives to positive change. Changes in life and experience are also gradually convincing, motivational and enthusiastic in essence and inspired constantly by positive examples. Marketing of the related sections includes marketing senses, feelings, thoughts and actions. Marketing related to an individual spreads private feelings beyond the customer closeness to home and thereby relates to something outside their private environment. Relate fighting to the customer need for personal development. They claim that they are strongly seen by everyone.

\section{Objectives of the Study}

- To study the customer satisfaction post car sales.

- To identify the satisfaction of the customer based on the customer loyalty and experience towards a service center post car sales.

- To analyze the reputation of the firm based on their customer satisfaction history.

\section{Data Collection}

Secondary Data: The collection of data via secondary sources including magazines, books, journals, newspapers, etc.

Primary Data: 300 reports from the questionnaire were collected from the customers using non-probability sampling from metro cities in India. There were 82.3\% of men and $17.7 \%$ of women. The respondents' average age was 25 years.

Period the study The reports of the study is said to collected between March 2017 - March 2021 across various metro cities of India on various service firms of reputed car brands.

\section{Hypothesis:}

Ho: There is no significant and positive influence on customer experience with customer loyalty post car sales in service industries

H1: There is a significant and positive influence on customer experience with customer loyalty post car sales in service industries

Ho: There is no significant and positive influence on customer experience with customer satisfaction post car sales in service industries

$\mathrm{H} 2$ : There is a significant and positive influence on customer experience with customer satisfaction post car sales in service industries

Analysis of Data: For the purpose of analysis, the study conducted Cronbach's alpha test with five-point scale in order to obtain the reliability of the 5-point scale. The reliability of various items are conducted and the overall reliability of the study is found to be 0.814 . Factor analysis is conducted to obtain all the three factor, since the study considers its factor loadings greater than 0.5 and therefore none of the items are removed. Further studying the factor reliability on all items, it is clear that the reliability of consumer experience is found to be 0.801 , the consumer loyalty is found to be 0.721 and consumer satisfaction is found to be 0.641 . Thus it can be conducted that the reliability scale is found to be reliable to conduct further analysis. From the Table 1, it is found that majority of the customers are agreeing with statements i.e. they very much experience a positive response from their service executives post car sales. The study is found to be reliable since the descriptive analysis for all the 23 statements shows the similar results, i.e. mean value is lesser than 2 .

a. Correlation Analysis: In order of finding the relationship between Customer Satisfaction, Customer Experience and Customer Loyalty, the study conducts a 
correlation study using Karl-Pearson coefficient. From the Table 2, it is seen that the correlation of all the three factors are found to be positive and significant, where the experience of customer experience and their satisfaction level is regarded positive with correlation value $r=0.528$. Secondly the experience of a customer is again considered positive since the value of the customer loyalty correlation is found to be $r=0.645$. Finally, the satisfaction of the customer with the value of the customer loyalty is found to be $r=0.603$. Therefore, the study concluded that there exist a positive correlation and significance in terms of customer emotions, satisfaction and loyalty.

Table 1. Descriptive

Statements

The supplier of knowledge is trying to touch my senses.

The supplier of knowledge is interesting perceptively.

I have little sensory attraction to the experienced supplier.

The supplier of expertise wants to put me in some mood.

The supplier of expertise lets me emotionally react.

The expert should not attempt to attract sentiments.

I am intrigued / interested by the experiences provider.

I'm curious about the experience supplier.

The supplier of knowledge should not strive to attract my artistic thinking.

I want to make my life care of the experience provider. The experience provider.

The expert recalls things that I would do.

The supplier of knowledge is not trying to get me to care about acts and behavior.

The supplier of expertise is trying to get me to learn about relationships.

Via this experience provider, I can connect with other people.

The supplier of expertise is not trying to remind me of social norms and regulations.

Customer Loyalty $(\alpha=.704)$

Tell other people good stuff about the supplier of knowledge.

Recommend a person looking for your advice to the experienced provider.

Encourage family and friends to visit the provider of the experience.

In the next two years, visit the experiencing provider more.

Consider the first pick for a leisure event to be the experience provider.

Customer Satisfaction $(\alpha=.637)$

My intention to visit here is pleasing to me.

I have more beyond my hopes in this experience.

Over all, I'm happy with my visit.

Mean

Std.

Factor

Deviation Loading

Customer Experience ( $\alpha=.729$ )

\begin{tabular}{|l|l|l|}
\multicolumn{3}{|c}{ Customer Experience $(\alpha=.729)$} \\
\hline 2.02 & .672 & .603 \\
\hline
\end{tabular}

\begin{tabular}{|c|c|c|}
\hline 2.02 & .672 & .603 \\
\hline 2.30 & .775 & .696 \\
\hline 2.69 & .908 & .685 \\
\hline 2.37 & .802 & .696 \\
\hline 2.34 & .825 & .658 \\
\hline 3.06 & .922 & .811 \\
\hline 2.12 & .726 & .651 \\
\hline 2.41 & .811 & .674 \\
\hline 2.84 & 1.129 & .828 \\
\hline 2.43 & .809 & .623 \\
\hline 2.05 & .706 & .575 \\
\hline 2.96 & .994 & .793 \\
\hline 2.23 & .768 & .666 \\
\hline 2.45 & .810 & .650 \\
\hline 2.66 & 1.046 & .796 \\
\hline 1.88 & .641 & .566 \\
\hline 2.27 & .795 & .737 \\
\hline 2.05 & .718 & .792 \\
\hline 2.30 & .867 & .674 \\
\hline 2.08 & .741 & .534 \\
\hline 1.84 & .581 & .587 \\
\hline 2.26 & .837 & .689 \\
\hline 2.03 & .649 & .726 \\
\hline
\end{tabular}

Table 2. Correlations

\begin{tabular}{|l|c|c|c|c|}
\hline \multirow{2}{*}{ Customer Satisfaction } & & CS & CE & CL \\
\hline & Pearson Correlation & 1 & & \\
\cline { 2 - 5 } & Sig. (2-tailed) & & & \\
\cline { 2 - 5 } & $\mathrm{N}$ & 300 & & \\
\hline \multirow{2}{*}{ Customer Experience } & Pearson Correlation & $.528^{* *}$ & 1 & \\
\cline { 2 - 5 } & Sig. (2-tailed) & .000 & & \\
\cline { 2 - 5 } & N & 300 & 300 & \\
\hline Customer Loyalty & Pearson Correlation & $.603^{* * *}$ & $.645^{* *}$ & 1 \\
\cline { 2 - 5 } & Sig. (2-tailed) & .000 & .000 & \\
\cline { 2 - 5 } & N & 300 & 300 & 300 \\
\hline \multirow{2}{*}{$* *$ Correlation is significant at the 0.01 level (2-tailed). } & & \\
\hline
\end{tabular}


a. Regression Analysis: In order to obtaining the impact of the experience of a customer based on the satisfaction and loyalty of the customer, the study uses regression analysis.

Impact of Customer Experience based on the Loyalty of a Customer.

The analysis found that the values of regression is found to be positive and significant in terms of customer satisfaction and customer experience with customer loyalty as its dependent variable. From the Table 3, we found that a total of $41.6 \%$ variance is reported on the customer loyalty based on the customer experience. The study thus reports that the impact as in Table 3 with dependent variable is significant having $\beta=.645 ; p<.01$.
Thus it is concluded that the customer experience often provides a positive and significant impact on customer loyalty and hence the hypothesis H1is considered accepted.

Impact of Customer Experience based on the Satisfaction of a Customer: From the Table 4, we found that a total of $27.9 \%$ variance is reported on the customer satisfaction based on the customer experience. The study thus reports that the impact as in Table 4 with dependent variable is significant having $\beta=.528 ; p<.01$. Thus it is concluded that the customer experience often provides a positive and significant impact on customer satisfaction and hence the hypothesis $\mathrm{H} 2$ is considered accepted. Thus it is concluded that the variance of customer loyalty is higher than the customer experience.

\begin{tabular}{|c|c|c|c|c|c|c|}
\hline \multirow[t]{2}{*}{ Model } & \multicolumn{2}{|c|}{ Unstandardized Coefficients } & \multirow[b]{2}{*}{ Beta } & \multirow{2}{*}{$\begin{array}{c}\text { Standardized } \\
\text { Coefficients }\end{array}$} & \multirow[t]{2}{*}{$\mathrm{T}$} & \multirow[t]{2}{*}{ Sig. } \\
\hline & B & Std. Error & & & & \\
\hline \multirow[t]{2}{*}{1} & (Constant) & .050 & .144 & & .346 & .729 \\
\hline & $\mathrm{CE}$ & .804 & .055 & .645 & 14.560 & .000 \\
\hline
\end{tabular}

a. Dependent Variable: Customer Loyalty

\begin{tabular}{|c|c|c|c|c|c|c|}
\hline \multirow[t]{2}{*}{ Model } & \multicolumn{2}{|c|}{ Unstandardized Coefficients } & \multirow[b]{2}{*}{ Beta } & \multirow{2}{*}{$\begin{array}{l}\text { Standardized } \\
\text { Coefficients }\end{array}$} & \multirow[t]{2}{*}{$\mathrm{T}$} & \multirow[t]{2}{*}{ Sig. } \\
\hline & B & Std. Error & & & & \\
\hline \multirow[t]{2}{*}{1} & (Constant) & .285 & .166 & & 1.721 & .086 \\
\hline & $\mathrm{CE}$ & .684 & .064 & .528 & 10.745 & .000 \\
\hline
\end{tabular}

a. Dependent Variable: Customer Satisfaction

Implications: This section provides the implications on how the experience providers enables positive experience of customer and their brand loyalty generates profit to the organisation with free branding of their product i.e. car post sales. Therefore, the hypothesis of the study concludes that the service providers should focus entirely on the customer satisfaction that enables improving the brand loyalty and satisfaction of customer with repeated purchases and services on a product.

\section{CONCLUSION}

The stud aims at analyzing the experience, loyalty and satisfaction of a customer with reference to experiential marketing. The feedback obtained from various customers across several states in India, the study can relate the positive response on experimental marketing in relation with customer satisfaction and loyalty. The findings of the study concludes that in order to shape a brand, the relationship with the consumer is important that involves empowering the brand identity, its affiliation and image.
Further the study suggest that an experience of a customer is likely obtains a positive and significant impact with the customer satisfaction and loyalty. These three elements leads to positive experiences that often acts a key player in improving the brand loyalty and positive strategy of experiential marketing. Thus experiential marketing enables the service provide to build a positive response and relation with its own consumer that acts as a positive building and free branding of the product.

\section{REFERENCES}

Ali Shah, I., Rajper, Z.A., Ali Ghumro, I. and Wahab Mahar, S., 2018. Experiential value mediates relationship between Experiential Marketing and Customer Satisfaction. Sukkur IBA Journal of Management and Business, 5(2), pp.45-61.

Araci, U.E., Bulut, Z.A. and Kocak, N., 2017. The relation among experiential marketing, customer satisfaction, and behavioral intention: A study on food and beverage businesses. Economic and Social Development: Book of 
Proceedings, pp.361-371.

Batat, W., 2019. Experiential marketing: Consumer behavior, customer experience and the 7Es. Routledge.

Boonmalert, W., Phoothong, B., Nualkaw, S. and Klakhaeng, P., 2020. The effect of market orientation and customer loyalty on business performance: An empirical evidence from rice industry of Thailand. PalArch's Journal of Archaeology of Egypt/Egyptology, 17(2), pp.602-616.

Budovich, L.S., 2019. Experiential marketing as a basis for modern communications with consumers. " Espacios", 40(06), p.16.

Datta, V., 2017. A conceptual study on experiential marketing: Importance, strategic issues and its impact. International Journal of Research-GRANTHAALAYAH, 5(7), pp.26-30.

Ero囚lu, F. and BAYRAKTAR KÖSE, E., 2019. Utilization of online influencers as an experiential marketing tool: A case of Instagram micro-celebrities. Journal of International Social Research, 12(63).

Ferreira, J. and Sousa, B., 2020. Experiential marketing as leverage for growth of creative tourism: a co-creative process. In Advances in Tourism, Technology and Smart Systems (pp. 567-577). Springer, Singapore.

Gallo, I., Townsend, C. and Alegre, I., 2019. Experiential product framing and its influence on the creation of consumer reviews. Journal of Business Research, 98, pp.177-190.

García, J.A.C., Galindo, A.D.V. and Suárez, R.M., 2018. The effect of online and offline experiential marketing on brand equity in the hotel sector. Spanish Journal of Marketing-ESIC.

Gheorghe, C.M., Gheorghe, I.R. and Purc冈rea, V.L., 2017. Modeling the consumer's perception of experiential marketing in the Romanian private ophthalmologic services. Romanian journal of ophthalmology, 61(3), p.219.

HONG, J.P., Kim, B.Y. and Oh, S.H., 2020. The Perceived-experiential Value and Service Quality of Auto Maintenance and Repair Service. The Journal of Distribution Science, 18(1), pp.59-69.

Ihtiyar, A., Barut, M. and Ihtiyar, H.G., 2019. Experiential marketing, social judgements, and customer shopping experience in emerging markets. Asia Pacific Journal of Marketing and Logistics.

Le, D., Scott, N. and Lohmann, G., 2019. Applying experiential marketing in selling tourism dreams. Journal of Travel \&t Tourism Marketing, 36(2), pp.220235.

Lee, J.W., Park, E.J. and Choi, M., 2017. The study on the effect of outdoor experiential marketing on brand and purchase intentions. Journal of Digital Convergence, 15(5), pp.139-150.

Levy, S. and Guterman, H.G., 2020. Twofold impact of experiential marketing: manufacturer brand and hosting retailer. EuroMed Journal of Business.
Lin, M.T.Y., 2019. Effects of Experiential Marketing on Experience Value and Customer Satisfaction in Ecotourism. Ekoloji Dergisi, (107).

Mukiira, E.M., Musau, M.C. and Munyao, M.J., 2017. Effect of experiential marketing in building brand equity: A case of selected Unilever Tanzania brands. International Journal of Supply Chain Management, 2(1), pp.1-31.

Muthiah, K. and Suja, S., 2017. A STUDY ON SENSE, FEEL, THINK, ACT, RELATE FACTORS OF EXPERIENTIAL MARKETING IN RETAILING. Transformations in Business \& Economics, 16(1).

Pratminingsih, S.A., Astuty, E. and Widyatami, K., 2018. Increasing customer loyalty of ethnic restaurant through experiential marketing and service quality. Journal of Entrepreneurship Education, 21(3), pp.1-11.

Ranjeeth, S. and Latchoumi, T.P., 2020. Predicting Kids Malnutrition Using Multilayer Perceptron with Stochastic Gradient Descent. Rev. d'Intelligence Artif., 34(5), pp.631-636.

Rather, R.A., 2020. Customer experience and engagement in tourism destinations: the experiential marketing perspective. Journal of Travel \& Tourism Marketing, 37(1), pp.15-32.

Rather, R.A., Hollebeek, L.D. and Islam, J.U., 2019. Tourism-based customer engagement: The construct, antecedents, and consequences. The Service Industries Journal, 39(7-8), pp.519-540.

Saravanan, V. and Raj, V.M., 2016. A Seamless Mobile Learning and Tension Free Lifestyle by QoS Oriented Mobile Handoff. Asian Journal of Research in Social Sciences and Humanities, 6(7), pp.374-389.

Saravanan, V. and Raj, V.M., 2016. Maximizing QoS by cooperative vertical and horizontal handoff for tightly coupled WiMAX/WLAN overlay networks. Cluster Computing, 19(3), pp.1619-1633.

Saravanan, V. and Sumathi, A., 2012. Handoff mobiles with low latency in heterogeneous networks for seamless mobility: A survey and future directions. European Journal of Scientific Research, 81(3), pp.417424.

Shieh, H.S. and Lai, W.H., 2017. The relationships among brand experience, brand resonance and brand loyalty in experiential marketing: Evidence from smart phone in Taiwan. Journal of Economics \& Management, 28, pp.57-73.

Skandalis, A., Byrom, J. and Banister, E., 2019. Experiential marketing and the changing nature of extraordinary experiences in post-postmodern consumer culture. Journal of Business Research, 97, pp.43-50.

Smilansky, S., 2017. Experiential marketing: A practical guide to interactive brand experiences. Kogan Page Publishers.

Suhaily, L. and Soelasih, Y., 2018. How e-service quality, experiential marketing, and price perception to make repurchase intention on online shopping. The 
International Journal of Business Management and Technology, 2(3), pp.10-20.

Sülük, S.B. and Aydin, K., 2019. Marketing communications and experiential marketing in the context of augmented reality. In Contemporary Issues in Behavioral Finance. Emerald Publishing Limited.

Tangkuman, M.J., Massie, J.D. and Mangantar, M.M., 2020. The Effect of Experiential Marketing And Customer Satisfaction on Customer Loyalty at Mcdonald's Manado. Jurnal EMBA: Jurnal Riset Ekonomi, Manajemen, Bisnis dan Akuntansi, 8(4).

Wahyuningtyas, F.M., Achmad, F. and Zainul, A., 2017. The effect of experiential marketing on satisfaction and its impact on customer loyalty. Russian Journal of Agricultural and Socio-Economic Sciences, 61(1).

Widowati, R. and Tsabita, F., 2017. The Influence Of Experiential Marketing On Customer Loyaltythrough Customer Satisfaction As Intervening Variable. Jurnal Manajemen Bisnis, 8(2), pp.163-180.

Wiedmann, K.P., Labenz, F., Haase, J. and Hennigs, N., 2018. The power of experiential marketing: exploring the causal relationships among multisensory marketing, brand experience, customer perceived value and brand strength. Journal of Brand Management, 25(2), pp.101118.

Yazıcı, T., Kocak, S. and Altunsöz, I.H., 2017. Examining the effect of experiential marketing on behavioral intentions in a festival with a specific sport event. European Sport Management Quarterly, 17(2), pp.171192.

Yeh, T.M., Chen, S.H. and Chen, T.F., 2019. The relationships among experiential marketing, service innovation, and customer satisfaction-A case study of tourism factories in Taiwan. Sustainability, 11(4), p. 1041.

Yookesh, T.L., Boobalan, E.D. and Latchoumi, T.P., 2020, March. Variational Iteration Method to Deal with Time Delay Differential Equations under Uncertainty Conditions. In 2020 International Conference on Emerging Smart Computing and Informatics (ESCI) (pp. 252-256). IEEE. 